\title{
WORD FORMATION ANALYSIS FOUND IN ENGLISH SLANGS USED BY JUSTIN BIEBER ON INSTAGRAM
}

\author{
Febi Gilang Pratama \\ Wiyaka \\ Entika Fani Prastikawati \\ English Education Departement \\ Universitas PGRI Semarang \\ entikafani@upgris.ac.id
}

\begin{abstract}
This study aimed to find out the word-formations in English slang utilized on Instagram captions posted by Justin Bieber. This study applied a descriptive qualitative method to capture the process of word-formation in Justin Bieber's English slang. In this study, the writers used the theory of Yule about the word-formation process for analyzing the data of English slang. The writers obtained the data through reading, capturing, and understanding the captions posted during a year (June 2020 - June 2021). Based on the data analysis, seven out of ten types of word-formation processes in English slang were used by Justin Bieber in his Instagram caption. They are (1) Clipping, (2) Blending, (3) Acronym, (4) Borrowing, (5) Derivation, (6) Coinage, and (7) Multi Processes. The most frequent type of word formation process used by Justin Bieber on Instagram is clipping with the 47 data's frequency (54\%). This study implies that Justin Bieber frequently used clipping to make short the words on every posted video or photo so his followers can easily understand his feeling.
\end{abstract}

Keywords: English Slang, Word formation, Instagram

\section{INTRODUCTION}

Language is a communication device that is used by people to convey messages to others in written or spoken. According to Spolsky (1998), language is used to express meaning and maintain the relationship. According to Kaye \& Downes (2000), language is representing the identity of the users of the language itself. When people speak to use the English language, they are using various English styles; one of the styles in the English language is the informal style. 
Slang is the everyday language that is frequently used in informal situations (Analysis et al., 2018) states that slang is a habitual language that is used among teenagers in a particular community with a specific interest. According to Tinggi \& Asing (2017), three communities regularly use slang words in their conversation such as musicians, drug users, and skateboarders. Slang language involves the developing of new words or dictions which never been existed before. In the process of creating slang words, there is a word-formation process that involves the existence of the words. For example, the word "woulda" included slanging word which means "would have". The process of word-formation "woulda" is blending which means the combination of two separate words which actually can stand alone. There are 10 types of process of word formation such as coinage, clipping, blending, compounding, borrowing, acronym, backformation, conversion, derivation, and multiple processes.

Currently, the massive spreading of social media also inflicts the spread of slang language; one of the social media platforms that have big numbers of active users is Instagram. According to Statista (2021), the news portal website that provides the statistic of the active users of Instagram, states that there are one billion active users use Instagram a month in June 2018. On Instagram when people post videos or photos, they can add captions. Mostly, they write caption use English slang word.

Some studies have revealed the use of slang in a movie, song lyrics, and social media. The use of slang is sometimes intended to show strong emotions feeling in humor (Zhou \& Fan, 2013). A study from Wulandari (2012) investigated the types of slang words found in the song lyrics. A descriptive method was used in this study. The finding shows that there are four types of the word-formation process of the slang words in the lyrics such as clipping (Uni, exam, and Sov), acronym (U.S), blending (wanna, kinda, ain't, shoulda, and let's), and backformation. They found 50 data of slang words. This findings implies that the most of slang words appears are denotative meanings which means it doesn't change the meaning; the focus of slang words that used in the song lyrics was making the good rhyme.

Tinggi \& Asing (2017) also used the qualitative descriptive method to find the slang used in seven songs by Meghan Trainor. There are three types of the word-formation process of the slang words in the lyrics such as clipping, blending, and coinage. As a study from Wulandari (2012), the slang words used in the song lyrics of this study were used for making the lyrics in a good rhyme.

Hafiza \& Rosa (2020) analyzed word-formation of English slang used in Straight Outta Compton Movie". In this study, it was found six types of slang words based on Yule's theory (2006). The data was taken from the movie script that there are 65 data of the slang words. The most often types 
of slang words that appeared in this study are blending with $29,24 \%$, which is 19 words. Then followed by coinage with $26,16 \%$, it is 17 words. After that followed by clipping with $24,66 \%$, it is 16 words. Then compounding with $13,84 \%$, it is 9 words. And the last one is an acronym and multiple processes with $3,07 \%$, it is 2 words. The study has revealed that most dirty words were used in the movie script as slang words. Most of the characters in the movie are showed that they are uneducated, lower caste, and criminals. This implies that the background of education, caste in society, and the community are influenced by the way they use the languages.

Harared (2018) investigated how slang was created and used in the website 1cak.com. Using a sociolinguistics study, it was found that there are 6 types of slang words, acronym, blending, borrowing, clipping, derivation, and initials. The data were taken from 'trending' and 'legend' posts on 1cak.site. Many slang terms found in this study were tended to a comedic. Many of them are acronyms or initials of certain words that only can be understood by the community of the "memer", or the people who are loving the meme (texts or images that contain humor-based slang). This can be implied that slang was created by a certain community with particular purposes as mentioned by Allan \& Burridge (2006).

Different from the previous studies, this study is trying to investigate the slang used by Justin Bieber in his Instagram. Investigating how a popular singer uses English slang in social media is crucial for the content of social media can influence the EFL learners in using their English in daily life communication (Tinggi \& Asing, 2017). For that reason, this study fills the exciting gap by investigating the slang used by Justin Bieber as a famous singer. This study is limited to a research question: "How is the process of word-formations in English slangs used in Justin Bieber's caption?"

Slangs

According to Fromkin et al. (2003), the term "slang" has been defined as a thing that everyone can realize but none of a single person can define. Slang also has a process of forming words, as Yule (2006) says such as Coinage, Clipping, Compounding, Blending, Borrowing, Back Formation, Acronyms, Conversions, Multiple processes, Derivation (Prefix, Infix, Suffix).

a) Coinage

Coinage is a word-formation process by inventing trade names for commercial products and using them in general terms.

b) Clipping

Clipping is one of the word-formation processes by making a long word or more than one syllable into a short form.

c) Compounding

Compounding is a word-formation process by combining two separate words to produce a new single word. 
d) Blending

Blending is one of the processes which combining two words to create a new word. It's by taking only the beginning of a word, then joining it to the end of the other word.

e) Borrowing

Borrowing is the one of word formation process by taking over words from other languages.

f) Backformation is a process of word-formation by reducing one type of word (usually a noun) to form a word of another type (usually a verb).

g) Conversions

Conversion is a process of forming a word by changing the function of the word (usually a noun to a verb) without any reduction.

h) Acronyms

Acronyms are a new word formed from the initial of a letter of the set of other words. i) Derivation

The derivation is a process of forming a word by adding a certain word (such as un-, mis-, -ish, -ism, and so, on). It could be at the beginning of the middle or in the last of the words.

j) Multiple Processes

Multiple processes refer to the process of forming a word that is more than one process.

\section{METHOD}

In this study, the writers used the descriptive qualitative method. The writers aimed to describe the types of slang words used by Justin Bieber based on Yule's theory of the word-formation process (2006). The data were collected using the observation method (Harared, 2018) that was applied during a year. In this case, the data was taken from Instagram the captions posted by Justin Beiber during June 2020 until June 2021. After collecting the data, the writers analyzed the data based on the theory of about three stages of analyzing the data such as data reduction, data display, and conclusion drawing/verification (Aldridge, 2002).

\section{FINDINGS AND DISCUSSION}

This section is trying to describe the finding that is related to the types of word-formation of slang words used by Justin Bieber on his Instagram's caption is presented in Table 1.

Based on the analysis of slang words used by Justin Bieber on Instagram's caption posted during a year (June 2020 - June 2021) there are 87 pieces of data collected in this analysis. From the data, we can conclude that the most frequent type of word formation that used by Justin Bieber is Clipping; 
which is 47 words or $54 \%$. There is also Blending, 18 words or $20,7 \%$. Then Derivation is 8 words or $9,2 \%$. After that is Acronym, it is 6 words or $6,9 \%$. Then, Borrowing and Coinage with the same numbers, it is 3 or $3,4 \%$. And the last is Multiple Processes, it is 2 or 2,3\%.

Table 1 The Frequency of Word Formation Process on Justin Bieber Instagram's Caption Posted.

\begin{tabular}{|c|c|c|c|}
\hline \multirow{2}{*}{ No } & \multirow{2}{*}{ Types of Word Formation } & \multicolumn{2}{|c|}{ Frequency } \\
\cline { 3 - 4 } & & Number & Percentage \\
\hline 1 & Clipping & 47 & $54 \%$ \\
\hline 2 & Blending & 18 & $20,7 \%$ \\
\hline 3 & Derivation & 8 & $9,2 \%$ \\
\hline 4 & Acronym & 6 & $6,9 \%$ \\
\hline 5 & Coinage & 3 & $3,4 \%$ \\
\hline 6 & Borrowing & 3 & $3,4 \%$ \\
\hline 7 & Multiple Processes & 2 & $2,3 \%$ \\
\hline Total & & 87 & $100 \%$ \\
\hline
\end{tabular}

\section{a. Clipping}

Clipping is one of the word-formation types in English slang that is shortening the word or few letters. From the data, the writer was found some clipping process of word-formation on Justin Bieber Instagram posted caption. These are the examples of clipping word-formation process on the Instagram caption posted by Justin Bieber:

Luv u sweet gurl

Slang: Luv

The word "luv" from the data above is a slang word that refers to love. It becomes a slang word because it's a new word that is created with a certain word formation process, the clipping process. The word luv is 
clipping from the word love by deleting the word e and changing the word o to $\mathrm{u}$. Another example is presented below:

Birthday gift love e $\underline{\text { em }}$

Slang: Em

The word " $\mathrm{em}$ " from the data above is a slang word that refers to them. It becomes a slang word because it includes word formation's process,

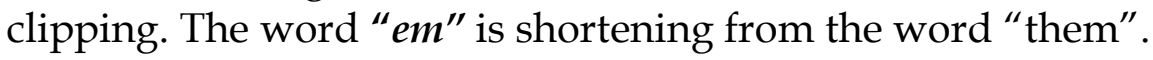

\section{b. Blending}

Blending is another process of word-formation type which associated to the process of forming English slang word. Blending is a word-formation process by combining one word with another word to create a new word. For example:

One of the most inspiring people $\underline{I^{\prime} v e}$ ever been around Slang: I've

The word "I've" is a slang word that refers to I have. It's two separate words combined into a new single word. They are "I" and "Have" and they can be classified into free morphemes because the two of them actually can stand alone. This word includes to slang word that classified into blending process of word formation; the word "I" + "Have". Further, Justin Beiber also used the following Blending in his caption:

Whole lotta...

Slang: lotta

The word "lotta" refers to a lot of or lots of. This word is included in slang, particularly, the word was formed within blending wordformation's process.

\section{c. Acronym}

In the process of word formation's type that stated by Yule (2006), there is also an acronym, which refers to the process of forming a new word by using the initial letters. This type of slang word also appears on Justin Bieber Instagram caption posted. For example:

Holding on is something [I] like do" who says that lol hope this makes you laugh.

The word " $l o l$ " is included in a slang word that is classified into acronym process. The word "lol" actually is the initial letter from the word "laugh out loud' which means to express something funny or amusing. 
Another is found in a caption below:

lil picnic wif $\underline{\text { bae }}$

The word "bae" in the sentence above refers to the acronym of "Before Anyone Else". It means a state of love feeling to someone such as sweetheart, baby, lovely, etc.

\section{d. Borrowing}

Borrowing is a process of word-formation type which refers to the process of creating a new single word by borrowing from other languages. This kind of slang word was also mentioned by Justin Bieber in his Instagram caption posted. This is found in a caption below:

My fur babies Oscar and Esther

The word "fur" is a slang word that is classified into the borrowing process. The word "fur" is borrowing from French which means "a sheath or cover". In French, fur used to mention a sheath that encases or covers a knife or sword made from hairy of an animal (Merriam-Webster Dictionary).

\section{e. Coinage}

Coinage refers to a process of forming a new word by inventing trade names for commercial products and using them in general terms. There is 3 word that included to coinage appears in this study. For example:

\section{glizzy tucked}

The word "glizzy" here, is classified into coinage. It is taken from an American product which is the name of a gun. Later, it changed into the name of hotdog. In this case, Bieber tried to say that his braces were looked like a hotdog.

\section{f. Derivation}

Derivation is another process of forming slang words by adding a certain word (such as, un-, mis-, -ish, -ism, and so, on). It could be in the beginning or in the middle or in the last of the words. For example:

When I'm tired, insecure, fearful, angry, sad...

The word "insecure" means not confident. It is classified into derivation word-formation process, especially, suffixes. The word "secure" got prefix "in" 


\section{g. Multiple Processes}

The last word-formation process in this study is multiple processes. Multiple processes refer to the process of forming a word that is more than one process. For examples:

When @djtayjames says put your hands up you put you mutha fuckin hands up happy Bday...

The word "mutha fuckin" here, is classified into multiple processes of word-formation process. First, it is blending from the word "motherfucker". Then the second process is clipping from the word "mother fucking". The word "mutha fuckin" here, means, remarkable or awesome.

From the result of the research above, it can be seen that there are four types of the word-formation process of slang words. They are clipping, blending, borrowing, and acronyms. The most frequent type of slang word used by Justin Bieber on his Instagram caption is Clipping with a percentage of $57,9 \%$.

In this study, there are 19 data collected analysis of the slang words. The most often used by Justin Bieber on his Instagram's caption is Clipping, it is 11 words. Then, Blending, it is 5 words. After that, there is Acronym, which is 2 words. And the last is Borrowing, it is 1 word. The data analysis indicated that the large numbers of the types of slang words are Clipping with 11 words then followed by Blending with 5 words. This indicated that Bieber as an influencer aimed to maintain the relationship with his fans. Bieber wanted to show his feeling through the captions posted on his videos or photos with a simple word. That is why Bieber used clipping in most of his captions posted and followed by blending. Bieber wanted to convey the messages with a simple shortened sentence, so that everyone, particularly his fans could understand the meaning.

From the analysis, the writer compared the study with other similar studies but it has different subjects and sources of the data. This study had differences from the studies (Analysis et al., 2018; Moreau, 2018; Wulandari, 2012; Tinggi \& Asing, 2017). The most dominant of the data sources from those 3 studies were taken from song lyrics, while the data of this study were taken from social media, Instagram, particularly on the caption that was posted by Justin Bieber. Besides the differences, there are similarities between this study and those 3 previous studies. The study and those 3 previous studies were found at least 2 similar types of slang words, they are clipping and blending.

Then, this study was also compared with other studies. Hafiza \& Rosa's study has differences from the author's study. The data of Hafiza and Rosa's study were taken from the movie script, while this is different from the 
author's study which was taken from the captions of Justin Bieber on Instagram. In Hafiza and Rosa's study, the most dominant type of slang word is blending while in this study clipping is the most frequent type of slang word.

The other study was done by Harared (2018). From Harared's study, it has similarities between this study. Both of the data of the study were taken from social media. The two studies also used the same theory while analyzing the slang words based on Yule's theory (2006). But there is a difference between the two studies. While the data sources of this study were specifically taken from Instagram's caption posted by Justin Bieber, an influencer. The data of Harared's study were particularly taken from the 1cak.com site, the website that provided the entertainment using meme (images and text that created humor-based slang).

\section{CONCLUSION}

There are 10 types of slang words based on Yule's (2006) theory about the word-formation process. In this study, the writer found 87 data of the slang words. The first type of slang word that appeared in big numbers is clipping then the second number is blending. This can be indicated that Justin Bieber tended to convey the messages in a short sentence. Bieber wanted to make short the sentence on his Instagram caption so that everyone could be easy to understand the meaning.

The researcher hopes that this study can be used as a reference to study slang words so that the next researcher can use different approaches, methods, and perspectives.

\section{REFERENCES}

Aldridge, D. (2002). Review: Michael Huberman \& Matthew B. Miles (Hrsg.) (2002). The Qualitative Researcher's Companion Review: Michael Huberman \& Matthew B. Miles (Eds.) (2002). The Qualitative Researcher's Companion Rese a: Michael Huberman \& Matthew B. Miles (Eds.) (2002). Forum Qualitative Sozialforschung / Forum: Qualitative Social Research, 3(4). https:// doi.org/10.17169/fqs-3.4.787

Allan, K., \& Burridge, K. (n.d.). Taboo and the Censoring of Language Sweet talking and offensive language. 29-54.

Analysis, A. N., Slang, O. F., In, W., Lyrics, S., \& On, E. (2018). An analysis of slang word in song lyric Eminem on album kamikaze. E-Journal of English Language \& Literature, 7(4).

Fromkin, V., Rodman, R., \& Hyams, N. (2003). An Introduction to Language sevent edition (p. 634).

Hafiza, M., \& Rosa, R. N. (2020). An analysis of word formation of english 
slang used in straight outta compton movie. E-Journal of English Language \& Literature ISSN, 9(1).

Harared, N. (2018). Slang Created and Used in 1Cak.com Site: A $\begin{array}{llll}\text { Sociolinguistics Study. Humaniora, 9(2), } & 119 .\end{array}$ https://doi.org/10.21512/humaniora.v9i2.4262

Kaye, A. S., \& Downes, W. (2000). Language and Society. Language, 76(1), 215. https:// doi.org/10.2307/417438

Moreau, E. (2018). What Is Instagram, Anyway? Lifewire, 1-9.

Putri Wulandari1, H. A. (2012). The types of slang words in the lyrics of "Jigsaw" album by Lady Sovereign. September, 1-16.

Spolsky Bernard. (1998). Sociolingustics (p. 71).

Tinggi, S., \& Asing, B. (2017). Identifying slang words in meghan trainor's song. $3(2)$.

Zhou, Y., \& Fan, Y. (2013). A sociolinguistic study of American slang. Theory and Practice in Language Studies, 3(12), 2209-2213. https://doi.org/10.4304/tpls.3.12.2209-2213 